\title{
Investigation of Corrosion Behavior of TinplateIn Fruit juice
}

\author{
Sourajyoti Dey ${ }^{1}$, Mahesh Kumar Agrawal $^{2}$ \\ ${ }^{1}$ Research scholar, Metallurgical \& Materials Engineering, National Institute of Technology; Jamshedpur, India \\ ${ }^{2}$ Professor, Metallurgical \& Materials Engineering, National Institute of Technology;Jamshedpur, India \\ 1 sourajyoti.dey@tatatinplate.com \\ 2mkagrawal_met@nitjsr.ac.in
}

\begin{abstract}
This paper aims to investigate the effect of corrosion of Tinplate containers for food packaging in fruit juices using a weight loss technique. Morphology\& structure of the corrosion products were characterized by scanning electron microscope (SEM). Test specimens of known weights were immersed in different type of fruit juices having with preservatives, natural fruit juice and water, for a total exposure period of 20 days. To determine the corrosion effect, the weight loss was measured at six day intervals. It is found that due to corrosion reaction, there was a significant degradation of tinplate sheet. Also an aggressive corrosion substance was detected. Results indicated that the corrosiveness of sweet fruit juice on container was due to a function of its acidity. Packed fruit juice with preservative was most corrosive followed by natural fruit juice and water, respectively.
\end{abstract}

Key words:Tinplate, corrosion, sweetening, food packaging,fruit juice, acidity.

\section{INTRODUCTION}

Packaging and containers have become tools for segregation and transportation of food. Food packaging and containers are made from different materials that vary from paper \& paper boards to glass vessels, and even to plastics and metals boxes \& cans.Various food preparations may contain, among other things, some acids, sweeteners, colorants and other additives that may impart organoleptic qualities to food ${ }^{[1]}$. In the production of various brands of citrus juices, the citrus species are utilized in many industries. This is because they are rich in vitamin $\mathrm{C}$, folic acid and significant quantities of other vitamins and flavonoids. The principal acid in citrus fruits is citric acid (80 to $90 \%$ of the total acids) and others are malic, tartaric, benzoic, succinic, oxalic and formic acids ${ }^{[2]}$.

During the preservation of canned citrus juices, an interaction occurs between the components of the canned food and the material of the can.Corrosion in canned acid products is frequently influenced by the chemical composition of the products, character of the tin plate and the presence of the corrosion accelerators such as sulfites, sulfur dioxide and oxygen ${ }^{[3]}$. Studies of corrosion mechanism have shown that the process involves dissolution of the tin coating and steel base with evolution of hydrogen ${ }^{[4]}$.

Food is canned in either plain tinplate or lacquered tin free steel. Although some food processing industries prefer to use lacquered tin plate which is very expensive but offers a longer shelf life. The quality of can is a major factor in the operations of food processing industries. Tin is considered to be quite resistant to attack by organic acids but undergoes corrosion if oxygen is present in the solution. In such cases, the food product may pick up corroded tin, which will affect the color and taste. With prolonged exposure, it may also have toxic effect on the quality of the food ${ }^{[5]}$.

Tinplate container for liquid food packaging is extensively use due to most of its advantages:

- These containers are made with plain carbon steel plates with thin tin-coating.

- $\quad$ Ease of packing and sterilizing.

- Anaerobic environment of the sealed can.

- $\quad$ Transporting and minimizing the loss of vitamin potency in food stuff.

Corrosion Mechanism:

All common structural metals form surface oxide films, when exposed to pure air but the oxide formed on mild steel is readily broken down, and in the presence of moisture, it is not repaired. Therefore, a reaction between steel $(\mathrm{Fe})$, moisture $\left(\mathrm{H}_{2} \mathrm{O}\right)$ and oxygen $\left(\mathrm{O}_{2}\right)$, takes place to form rust ${ }^{[6]}$ and mild steel corrodes easily. This reaction is complex but it can be represented by a chemical equation of the following type:

$$
4 \mathrm{Fe}+\mathrm{H}_{2}+3 \mathrm{O}_{2}=2 \mathrm{Fe}_{2} \mathrm{O}_{3} \cdot \mathrm{H}_{2} \mathrm{O}
$$

$\mathrm{Fe}_{2} \mathrm{O}_{3} \cdot \mathrm{H}_{2} \mathrm{O}$ is the rust, and it is not usually protective; therefore, the corrosion process is not inhibited. In an empty tin can, the tin plate is cathodic and the steel base is anodic.This is kept from the corrosion-vulnerable mild steel base by the corrosion resistant tin layer. In case of corrosive acidic liquid, a reversal of polarity takes place. Tin now becomes the local anode and steel base the local cathode. Thus, the protective mode of the tin 
plate is now via an electrochemical process and this happens in canned acidic fruit juices such as citrus juices.Schematically the whole process of corrosion has been illustrated in figure 1 .

The attack on tin by fruit juices depends very largely on the formation of complexes in fruit acid such as oxalic, citric and malic acids. Complexing anions can influence the relative position of Sn, Fe and Sn-Fe alloy. Addition of food additives such as colorants, flavor, sweeteners and preservatives, affects the characteristic of the food.Their corrosively may be due to the fact that they contain two or more Sulphuric acid groups that form soluble compound ${ }^{[7]}$. Another possibility of increase in corrosion rate is the presence of hydroxyl groups in that form complexes with metal ions that inhibit corrosion.

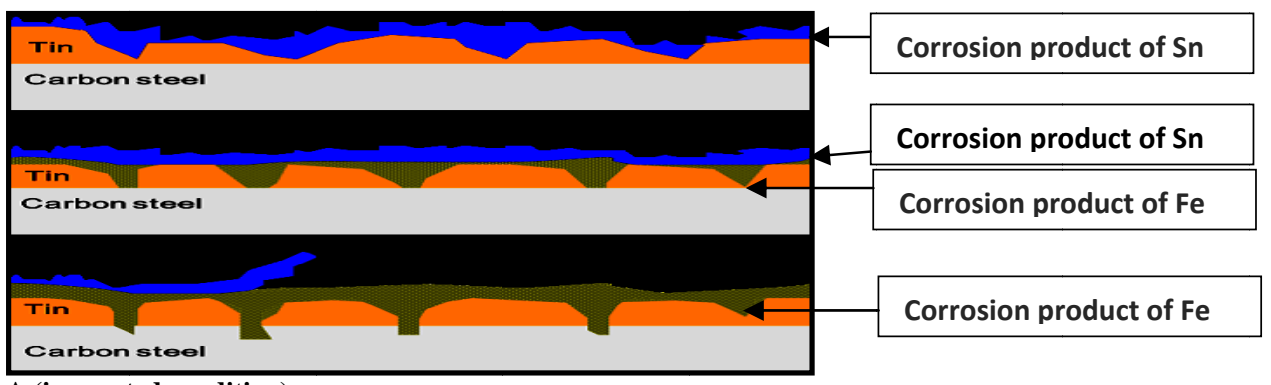

A (in aerated condition)

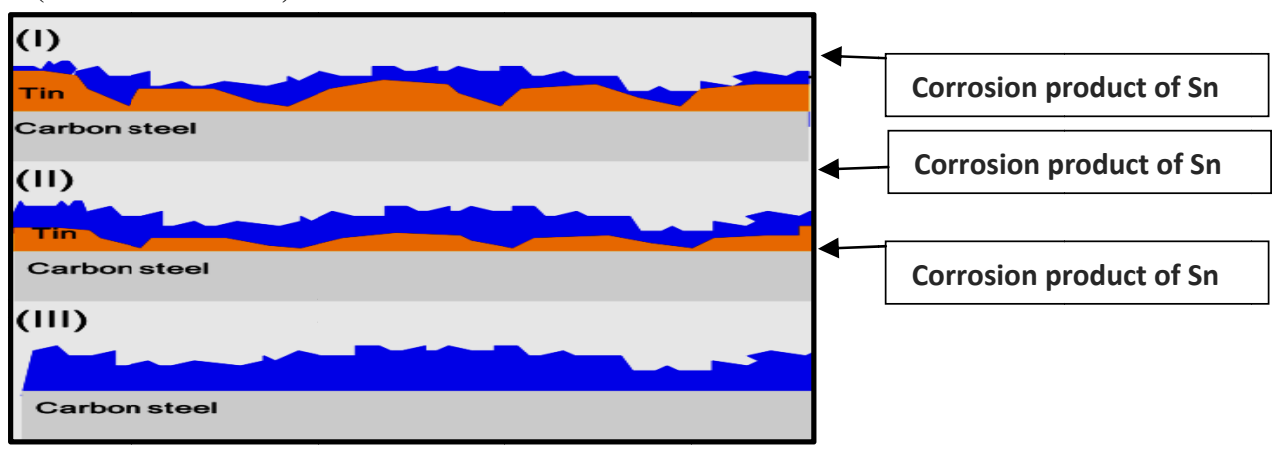

Fig.1 - Schematic diagrams of the corrosion mechanism of tinplate

However, most of the investigations are based on direct use of preventives such citric acid, malic acid etc. corrosive medium. The results obtained in that investigation could not directly applied to the actual can manufacturer who wish to store actual food items which may contain preservatives in different proportions. The methodology used in the investigation is direct and simple and can be utilized by simple modification of process parameters. It provide a better understanding of the corrosiveness behavior of the fruit juices, thereby enhancing the material selection and effective surface treatment to increase corrosion resistance ${ }^{[8]}$. The results would help the can-makers to estimate shelf life of the container.

\section{EXPERIMENTAL}

Uniformly high tin-coated plates used for canning fruit juice were used. The composition of the steel base plate is given in following table.

Table 1: chemical composition of steel

\begin{tabular}{|c|c|c|c|c|c|c|c|c|c|c|c|}
\hline Elements & $\mathbf{C}$ & $\mathbf{M n}$ & $\mathbf{S i}$ & $\mathbf{P}$ & $\mathbf{S}$ & $\mathbf{C u}$ & $\mathbf{~ N i}$ & $\mathbf{C r}$ & $\mathbf{M o}$ & $\mathbf{A l}$ & $\mathbf{F e}$ \\
\hline Weight(\%) & 0.08 & 0.35 & 0.03 & 0.03 & 0.03 & 0.2 & 0.15 & 0.1 & 0.05 & 0.02 & Rest \\
\hline
\end{tabular}

Four samples were cut into sizes of $50 \mathrm{~mm} \times 50 \mathrm{~mm}$. The initial tin-coating wt. of the surface was $11.2 \mathrm{~g} / \mathrm{m}^{2}$.Pre experimental treatment that can affect the texture and expose the steel surface, like grinding, was avoided. Samples were subjected to thorough cleaning by washing in acetone to remove dirt and any grease of oil. The sharp edges were smoothened using abrasive paper to prevent misleading corrosion results.

\section{A. Sample collection:}

- First 4 samples were collected from the tinplate sheet coated with tin amount 11.2/5.6 (Top/Bottom) $\mathrm{g} / \mathrm{m}^{2}$.The exposure face was $11.2 \mathrm{~g} / \mathrm{m}^{2}$ tin coated side and the side of 5.6 coating was lacquered with food grade lacquer.

- Second 4 samples were collected from the tinplate sheet coated with tin amount 5.6/5.6 (Top/Bottom) $\mathrm{g} / \mathrm{m}^{2}$.The exposure face was $5.6 \mathrm{~g} / \mathrm{m}^{2}$ tin coating on one side and the other side was lacquered with food grade lacquer. 


\section{B. Preparation of corrosive media:}

To study the effect of fruit juice on the corrosion of tin plates, four different juices were used namely: Lichi juice, Mango juice, Orange juice and Pine apple juice. The concentrations of the juices were adopted within the normal industrially acceptable levels. Juices contain fruit juice, water, sugar and preservative.

\section{Test procedure:}

Corrosion study was carried out in two sets by total immersion of test specimen in corrosive media at room temperature. Each set have 4 nos. of glass container with air tight lid containing the above four different juices.

Each test piece of tinplate was suspended in corrosive media by attaching the test piece with nylon thread and properly labeled. Same experiment was repeat also at below the room temperature $\left(10^{\circ} \mathrm{C}\right)$ and in hot condition $\left(55^{\circ} \mathrm{C}\right)$. The following experimental variants were performed in two sets.A schematic diagram of the experimental set illustrated in fig.2.

Table 2: Variants and sample details.

\begin{tabular}{|c|c|c|c|c|c|}
\hline \multirow{2}{*}{$\begin{array}{l}\text { Expt. } \\
\text { set }\end{array}$} & \multirow[t]{2}{*}{ Sample details } & \multicolumn{4}{|c|}{ VAR I A NTS } \\
\hline & & Variant-1 & Variant-2 & Variant-3 & Variant-4 \\
\hline 1 & $\begin{array}{l}11.2 / 5.6 \mathrm{~g} / \mathrm{m}^{2} \text { coated tinplate sample of } \\
50 \times 50 \mathrm{~mm}^{2} \text { size. Exposure side was } \\
11.2 \mathrm{~g} / \mathrm{m}^{2} \text { coated and the side of } \\
5.6 \mathrm{~g} / \mathrm{m}^{2} \text { coated was covered with food } \\
\text { lacquer. }\end{array}$ & $\begin{array}{l}\text { LICHI } \\
\text { JUICE }\end{array}$ & $\begin{array}{l}\text { MANGO } \\
\text { JUICE }\end{array}$ & $\begin{array}{l}\text { ORANGE } \\
\text { JUICE }\end{array}$ & $\begin{array}{l}\text { PINE } \\
\text { APPLE } \\
\text { JUICE }\end{array}$ \\
\hline 2 & $\begin{array}{l}5.6 / 5.6 \mathrm{~g} / \mathrm{m}^{2} \text { coated tinplate sample of } \\
50 \times 50 \mathrm{~mm}^{2} \text { size. One side of sample } \\
\text { was covered with food lacquer. }\end{array}$ & $\begin{array}{l}\text { LICHI } \\
\text { JUICE }\end{array}$ & $\begin{array}{l}\text { MANGO } \\
\text { JUICE }\end{array}$ & $\begin{array}{l}\text { ORANGE } \\
\text { JUICE }\end{array}$ & $\begin{array}{l}\text { PINE } \\
\text { APPLE } \\
\text { JUICE }\end{array}$ \\
\hline
\end{tabular}
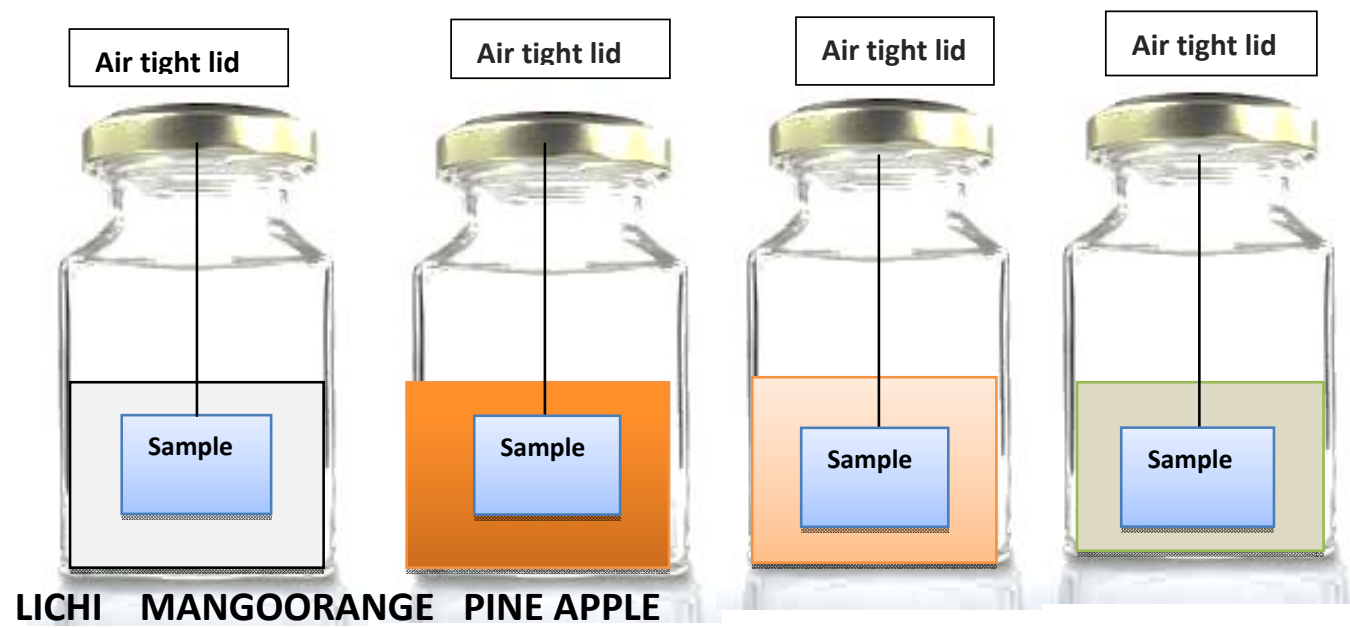

Fig.2: Schematic diagram of experimental sets

The experiment wascarried out for 20 days, after which there was de-tinning and an appearance of pitting corrosion on the steel plate appeared.Corrosion Rate was assessed by the conventional weight loss method and visual observation of test pieces. Microprocessor controlled $\mathrm{pH}$ meter was used to monitor and measure the $\mathrm{pH}$ variation with time of the corroding media. Data obtained are used in assessment of experimental results.

The test pieces were weighted on digital electronic balance calculate the weight loss as per given formula.

Weight Loss $(\mathrm{W})=\mathrm{w}_{1}-\mathrm{W}_{2}$

$$
\begin{aligned}
& \text { Where } \mathrm{W}=\text { metal weight loss (mg) } \\
& \mathrm{w}_{1}=\text { Initial weight } \\
& \mathrm{w}_{2}=\text { Final weight }
\end{aligned}
$$


Hence, Corrosion rate (millimeter/ year) was calculated using the following equation:

Corrosion rate $\mathrm{mm} / \mathrm{y}=87.6 \mathrm{x}\left(\mathrm{W} / \mathrm{D}^{*} \mathrm{~A} * \mathrm{~T}\right)$

Where, $\mathrm{W}=$ wt. loss in milligrams

$$
\begin{aligned}
& \mathrm{D}=\text { metal density in } \mathrm{g} / \mathrm{cm}^{3}\left(7.2287 \mathrm{~g} / \mathrm{cm}^{3} \text { for tin }\right) \\
& \mathrm{A}=\text { area of sample in } \mathrm{cm}^{2} \\
& \mathrm{~T}=\text { time } \mathrm{f} \text { exposure of the metal sample in hours } \\
& 87.6 \text { = constant factor }
\end{aligned}
$$

\section{III.RESULT}

Findings of the experiment tabulated below:

Table 3: $\mathrm{pH}$ of all variant at a regular interval for 6 days.

\begin{tabular}{|c|c|c|c|c|}
\hline $\begin{array}{c}\text { Observation } \\
\text { Day }\end{array}$ & Lichi Juice & Mango Juice & Orange Juice & $\begin{array}{c}\text { Pine Apple } \\
\text { Juice }\end{array}$ \\
\hline 2 & 2.93 & 3.09 & 3.61 & 3.48 \\
\hline 3 & 2.85 & 3.05 & 3.56 & 3.37 \\
\hline 4 & 2.85 & 3.05 & 3.54 & 3.21 \\
\hline 5 & 2.81 & 3.01 & 3.55 & 3.18 \\
\hline 6 & 2.79 & 3.01 & 3.55 & 3.14 \\
\hline
\end{tabular}

Observation was started from second day of start of experiment (after 24 hour duration)

\begin{tabular}{|c|c|c|c|c|c|c|c|c|}
\hline \multirow[t]{3}{*}{$\begin{array}{l}\text { Exposure time } \\
\text { (Hours) }\end{array}$} & \multicolumn{2}{|c|}{$\begin{array}{c}\text { Variant } 1 \\
\text { Lichi juice }\end{array}$} & \multicolumn{2}{|c|}{$\begin{array}{c}\text { Variant } 2 \text { Mango } \\
\text { juice }\end{array}$} & \multicolumn{2}{|c|}{$\begin{array}{c}\text { Variant } 3 \text { Orange } \\
\text { juice }\end{array}$} & \multicolumn{2}{|c|}{$\begin{array}{c}\text { Variant } 4 \\
\text { Pine app. juice }\end{array}$} \\
\hline & \multicolumn{2}{|c|}{$\begin{array}{c}\text { Corrosion rate } \\
(\mathrm{mm} / \mathrm{yr})\end{array}$} & \multicolumn{2}{|c|}{$\begin{array}{c}\begin{array}{c}\text { Corrosion rate } \\
(\mathrm{mm} / \mathrm{yr})\end{array} \\
\end{array}$} & \multicolumn{2}{|c|}{$\begin{array}{c}\text { Corrosion } \\
\operatorname{rate}(\mathbf{m m} / \mathbf{y r})\end{array}$} & \multicolumn{2}{|c|}{$\begin{array}{c}\text { Corrosion rate } \\
(\mathrm{mm} / \mathrm{yr})\end{array}$} \\
\hline & 11.2 & 5.6 & 11.2 & 5.6 & 11.2 & 5.6 & 11.2 & 5.6 \\
\hline 24 & 0.0500 & 0.0560 & 0.0300 & 0.0180 & 0.0211 & 0.0160 & 0.0400 & 0.0340 \\
\hline 48 & 0.0279 & 0.0380 & 0.0242 & 0.0180 & 0.0206 & 0.0142 & 0.0297 & 0.0320 \\
\hline 96 & 0.0235 & 0.0117 & 0.0202 & 0.0130 & 0.0191 & 0.0115 & 0.0241 & 0.0252 \\
\hline 144 & 0.0223 & 0.0302 & 0.0171 & 0.0093 & 0.0169 & 0.0102 & 0.0191 & 0.0201 \\
\hline 192 & 0.0219 & 0.0231 & 0.0149 & 0.0080 & 0.0151 & 0.0086 & 0.0157 & 0.0152 \\
\hline 240 & 0.0179 & 0.0202 & 0.0121 & 0.0056 & 0.0121 & 0.0072 & 0.0106 & 0.0136 \\
\hline 360 & 0.0157 & 0.0133 & 0.0112 & 0.0052 & 0.0108 & 0.0067 & 0.0105 & 0.0096 \\
\hline 480 & 0.0189 & 0.0072 & 0.0129 & 0.0068 & 0.0133 & 0.0076 & 0.0120 & 0.0076 \\
\hline
\end{tabular}

Table 4: Weight loss of the sample in different variant

\begin{tabular}{|c|c|c|c|c|c|c|c|c|}
\hline \multirow{2}{*}{$\begin{array}{c}\text { Exposure time } \\
\text { (Hours) }\end{array}$} & \multicolumn{2}{|c|}{$\begin{array}{c}\text { Weight loss(g) } \\
\text { (Lichi Juice) }\end{array}$} & \multicolumn{2}{c|}{$\begin{array}{c}\text { Weight loss(g) } \\
\text { (Mango Juice) }\end{array}$} & \multicolumn{2}{c|}{$\begin{array}{c}\text { Weight loss(g) } \\
\text { (Orange Juice) }\end{array}$} & \multicolumn{2}{c|}{$\begin{array}{c}\text { Weight loss(g) } \\
\text { (Pine Apple Juice) }\end{array}$} \\
\cline { 2 - 9 } & $\mathbf{1 1 . 2}$ & $\mathbf{5 . 6}$ & $\mathbf{1 1 . 2}$ & $\mathbf{5 . 6}$ & $\mathbf{1 1 . 2}$ & $\mathbf{5 . 6}$ & $\mathbf{1 1 . 2}$ & $\mathbf{5 . 6}$ \\
\hline 24 & 0.0025 & 0.0027 & 0.0015 & 0.0009 & 0.0007 & 0.0008 & 0.0020 & 0.0020 \\
\hline 48 & 0.0028 & 0.0024 & 0.0014 & 0.0018 & 0.0015 & 0.0010 & 0.0021 & 0.0022 \\
\hline 96 & 0.0047 & 0.0020 & 0.0015 & 0.0026 & 0.0027 & 0.0011 & 0.0027 & 0.0029 \\
\hline 144 & 0.0067 & 0.0028 & 0.0016 & 0.0028 & 0.0044 & 0.0019 & 0.0027 & 0.0039 \\
\hline 192 & 0.0030 & 0.0037 & 0.0019 & 0.0032 & 0.0036 & 0.0050 & 0.0029 & 0.0061 \\
\hline 240 & 0.0070 & 0.0042 & 0.0021 & 0.0051 & 0.0029 & 0.0052 & 0.0042 & 0.0068 \\
\hline 360 & 0.0118 & 0.0047 & 0.0064 & 0.0078 & 0.0081 & 0.0057 & 0.0079 & 0.0072 \\
\hline 480 & 0.0189 & 0.0072 & 0.0129 & 0.0156 & 0.0133 & 0.0076 & 0.0120 & 0.0076 \\
\hline
\end{tabular}

Table 5: Exposure time and corrosion rate of the sample in each variant 
Table 6: Corrosion rate at $10^{\circ} \mathrm{C}$ and at $55^{\circ} \mathrm{C}$.

\begin{tabular}{|c|c|c|c|c|c|c|c|c|}
\hline $\begin{array}{c}\text { Exposure } \\
\text { time } \\
\text { (Hours) }\end{array}$ & $\begin{array}{c}\text { Variant 1 } \\
\text { Lichi juice }\end{array}$ & \multicolumn{2}{c|}{$\begin{array}{c}\text { Variant 2 } \\
\text { Mango juice }\end{array}$} & \multicolumn{2}{c|}{$\begin{array}{c}\text { Variant 3 } \\
\text { Orange juice }\end{array}$} & \multicolumn{2}{|c|}{$\begin{array}{c}\text { Variant 4 } \\
\text { Pine app. Juice }\end{array}$} \\
\cline { 2 - 8 } & $\begin{array}{c}\text { Corrosion } \\
\text { rate (mm/yr) }\end{array}$ & \multicolumn{2}{c|}{$\begin{array}{c}\text { Corrosion rate } \\
(\mathbf{m m} / \mathbf{y r})\end{array}$} & \multicolumn{2}{c|}{$\begin{array}{c}\text { Corrosion rate } \\
(\mathbf{m m} / \mathbf{y r})\end{array}$} & \multicolumn{2}{c|}{$\begin{array}{c}\text { Corrosion rate } \\
(\mathbf{m m} / \mathbf{y r})\end{array}$} \\
\hline & $\mathbf{1 1 . 2}$ & $\mathbf{5 . 6}$ & $\mathbf{1 1 . 2}$ & 5.6 & $\mathbf{1 1 . 2}$ & 5.6 & 11.2 & 5.6 \\
\hline $\begin{array}{c}24 \mathrm{hr} \text { at } \\
10^{\circ} \mathrm{C}\end{array}$ & $\mathbf{0 . 0 4 8}$ & $\mathbf{0 . 0 2 2}$ & $\mathbf{0 . 0 1 0}$ & $\mathbf{0 . 0 1 6}$ & $\mathbf{0 . 0 1 8}$ & $\mathbf{0 . 0 1 8}$ & $\mathbf{0 . 0 2 6}$ & $\mathbf{0 . 0 4 0}$ \\
\hline $\begin{array}{c}24 \mathrm{hr} \text { at } \\
55^{\circ} \mathrm{C}\end{array}$ & $\mathbf{0 . 0 7 2}$ & $\mathbf{0 . 0 8 4}$ & $\mathbf{0 . 0 7 2}$ & $\mathbf{0 . 0 3 4}$ & $\mathbf{0 . 0 7 2}$ & $\mathbf{0 . 0 6 6}$ & $\mathbf{0 . 0 9 6}$ & $\mathbf{0 . 1 2 8}$ \\
\hline
\end{tabular}

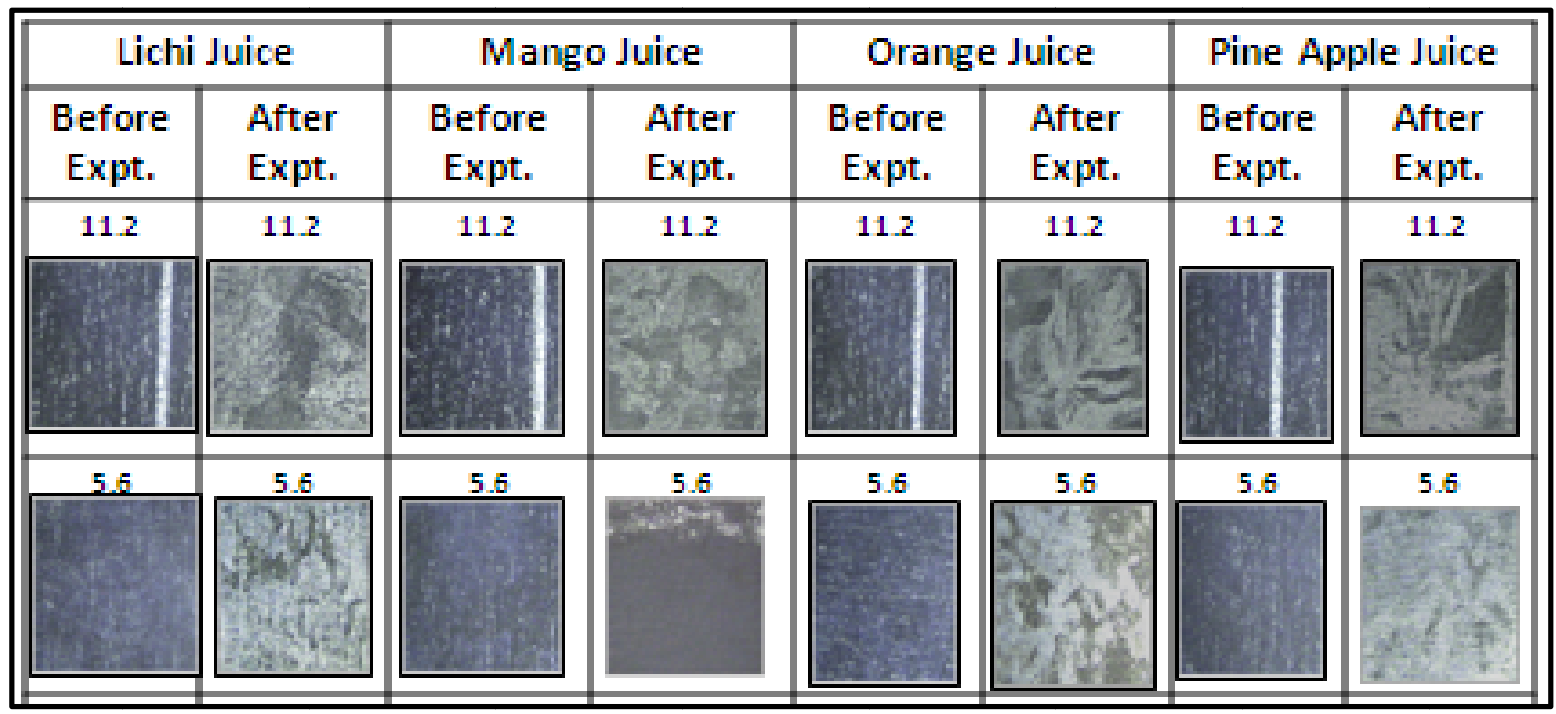

Fig. 3: Comparative photograph of the sample before and after the experiment Morphology and composition

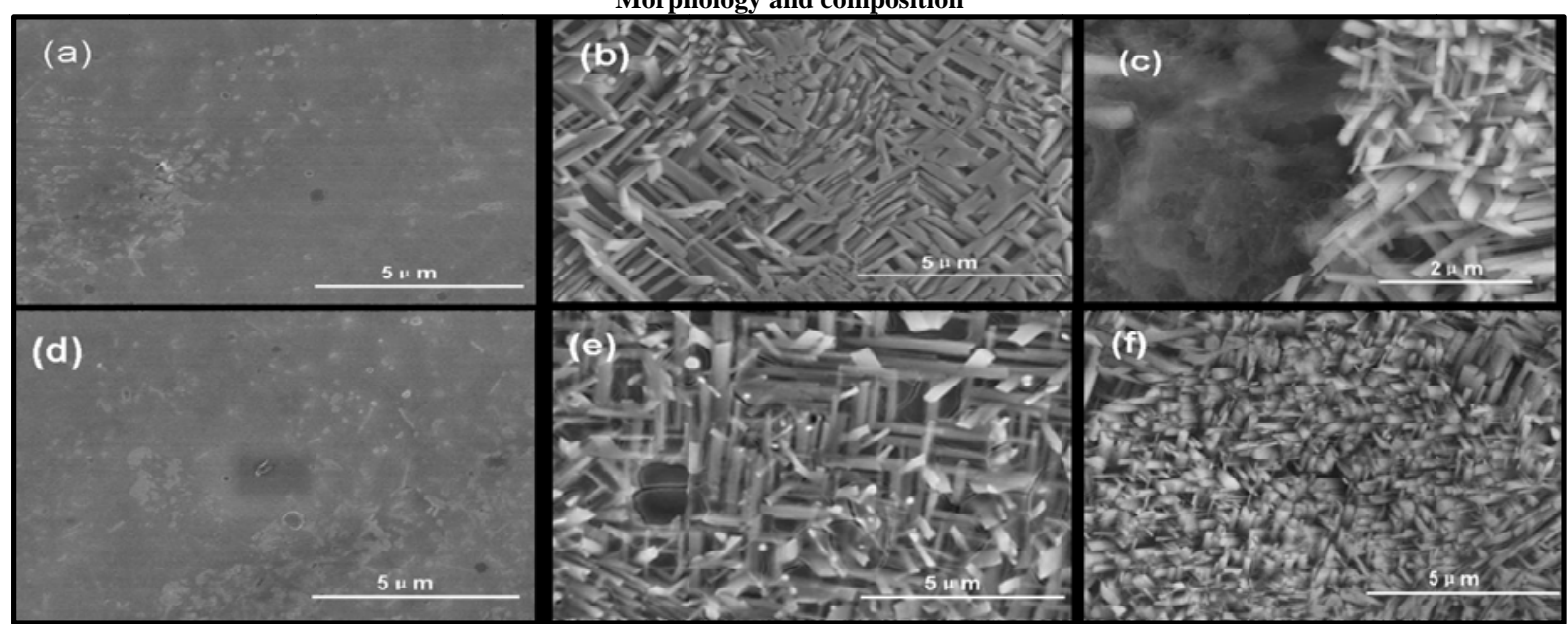

Fig. 4: SEM surface images of tinplate

Figure (a)\&(d) represent the surface of tinplate sample before the experiment Figure (b)\&(e) represent the surface after exposed to citric acid solution for 10days

and figure (c)\&(f) represent the surface after exposure of acid for 20 days

After experiment, large amount of stick-shaped corrosion products that covered the whole surface could be observed on the sample surface after immersion for 20 days 


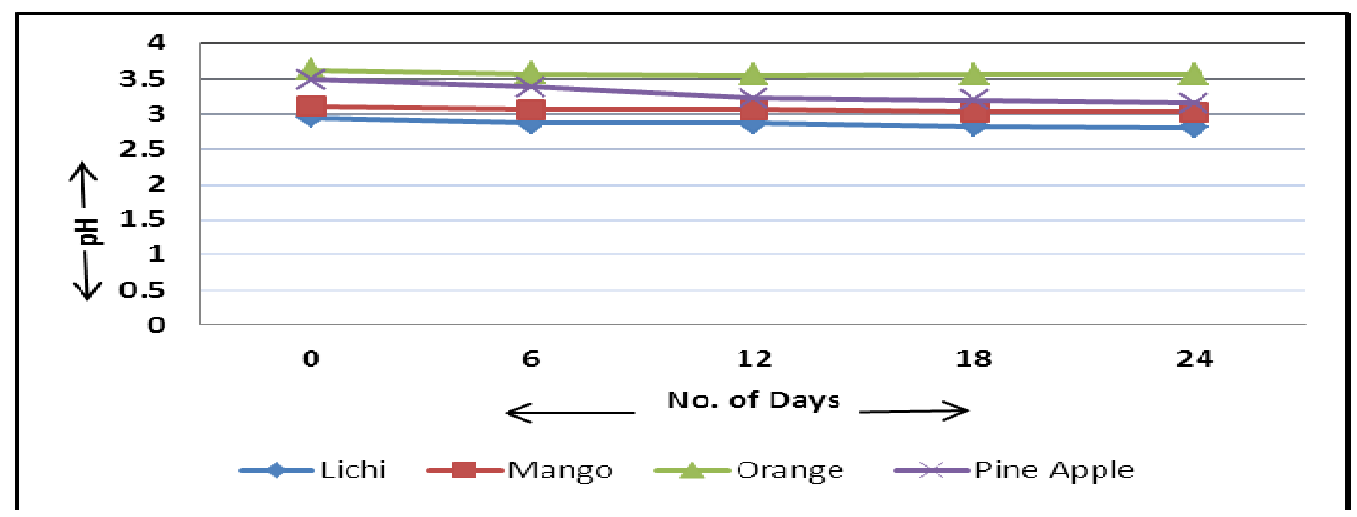

Fig. 5: variation of $\mathrm{pH}$ vs no. of days

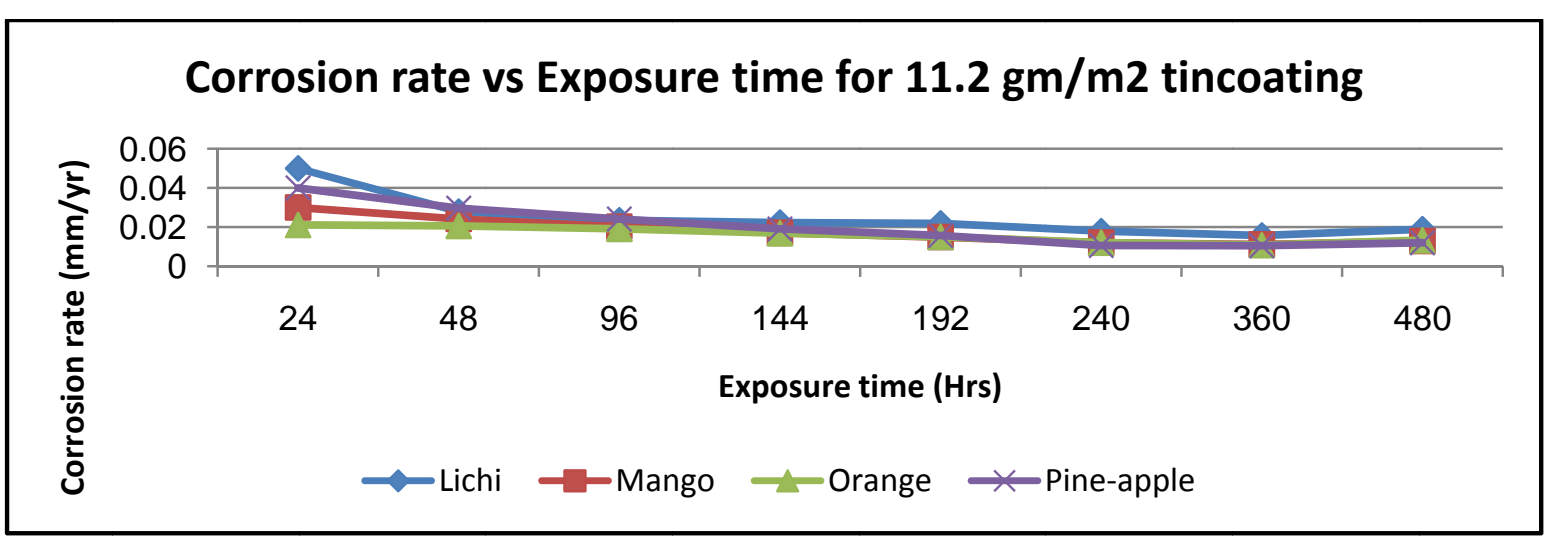

Fig. 6: Corrosion Rate vs Exposure time for $11.2 \mathrm{gm} / \mathrm{m}^{2}$ tin-coating

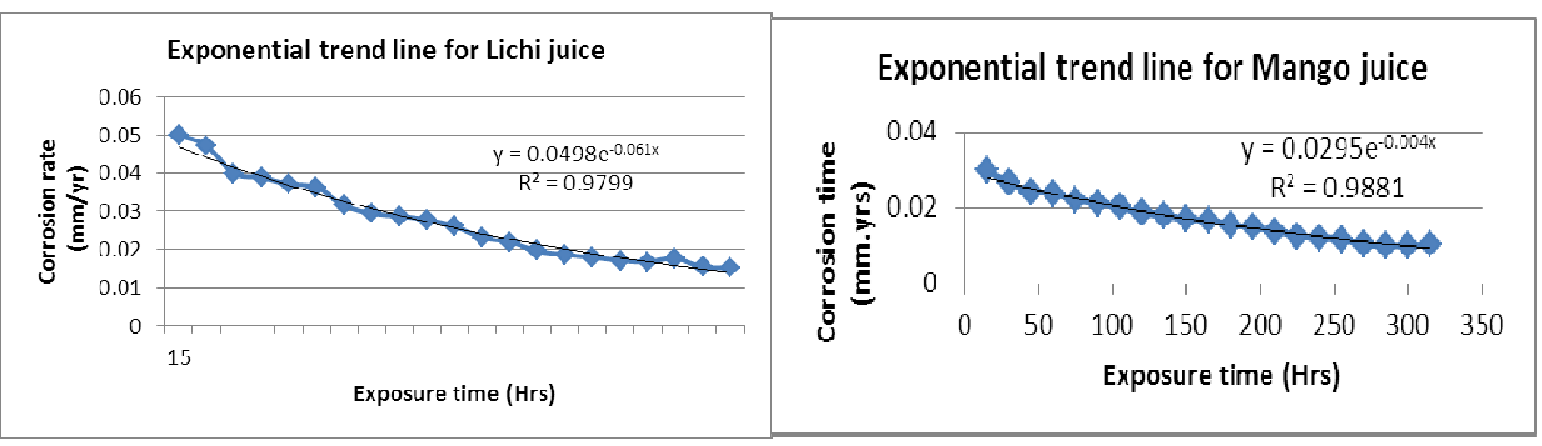

Co-relation graph for Lichi juice Co-relation graph for Mango juice

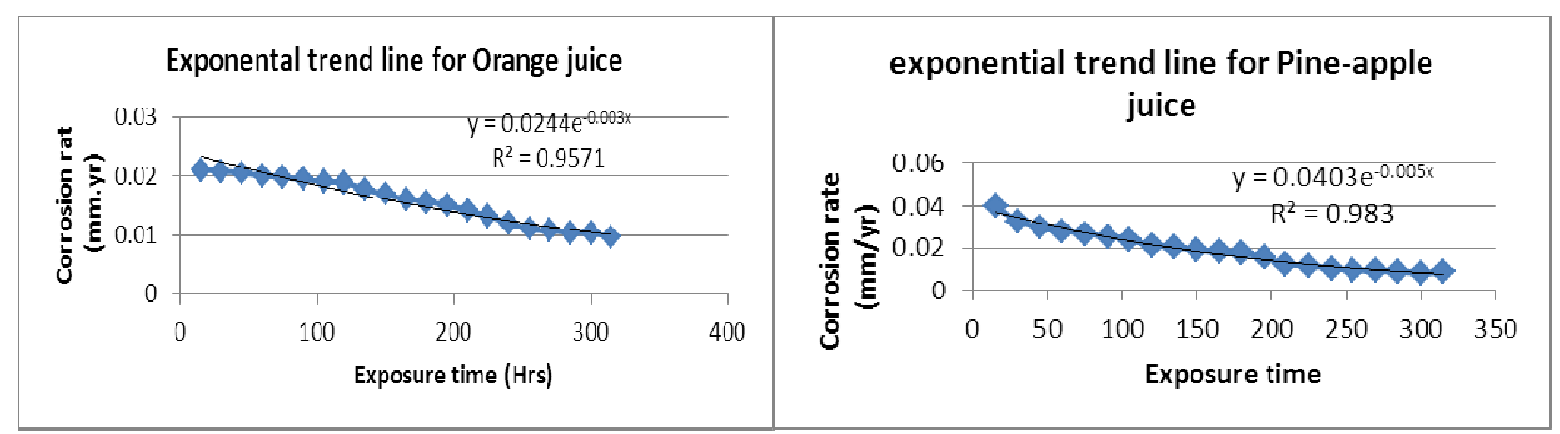

Co-relation graph for Orange juice Co-relation graph for Pine-apple juice

Fig. 7: Co-relation graph for 4 different variants ( $\mathrm{R}=$ regression coefficient) 


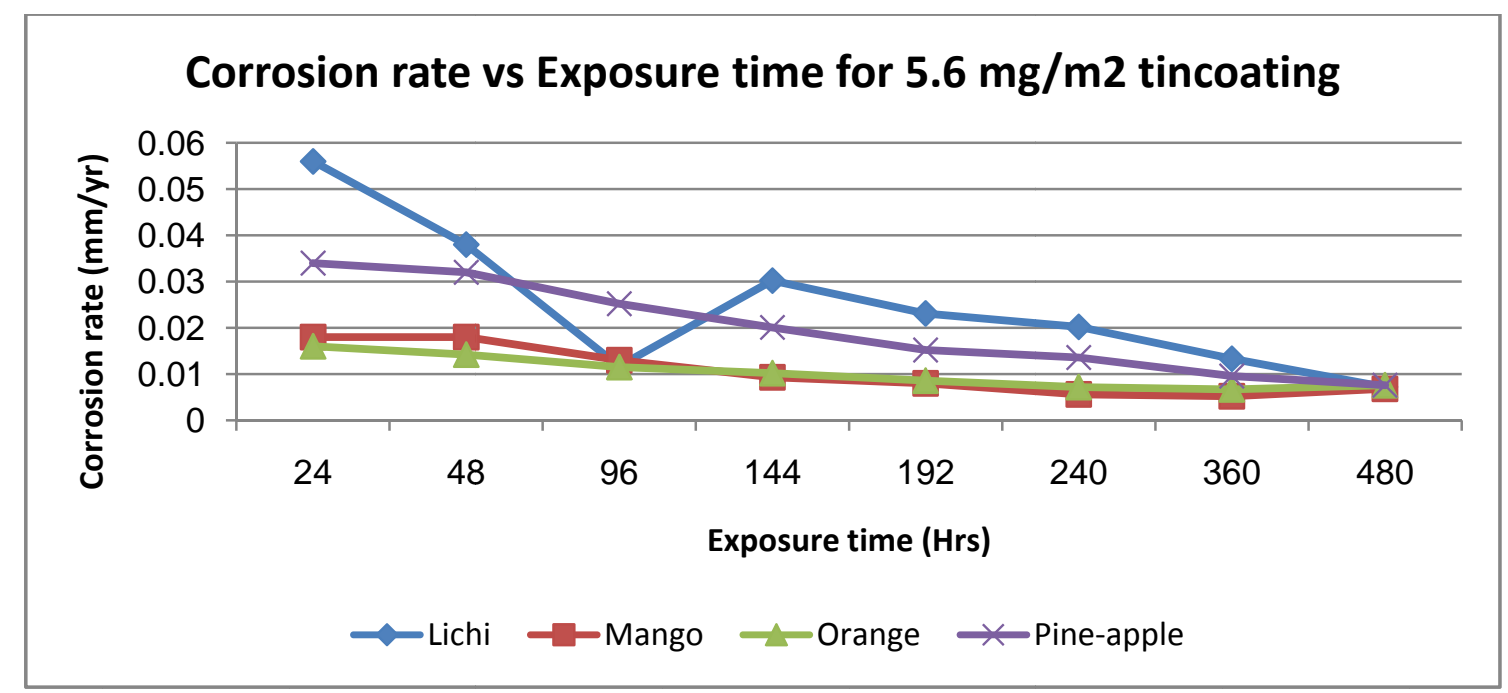

Fig. 8: Corrosion Rate vs. Exposure time for $5.6 \mathrm{gm} / \mathrm{m}^{2}$ tin coating

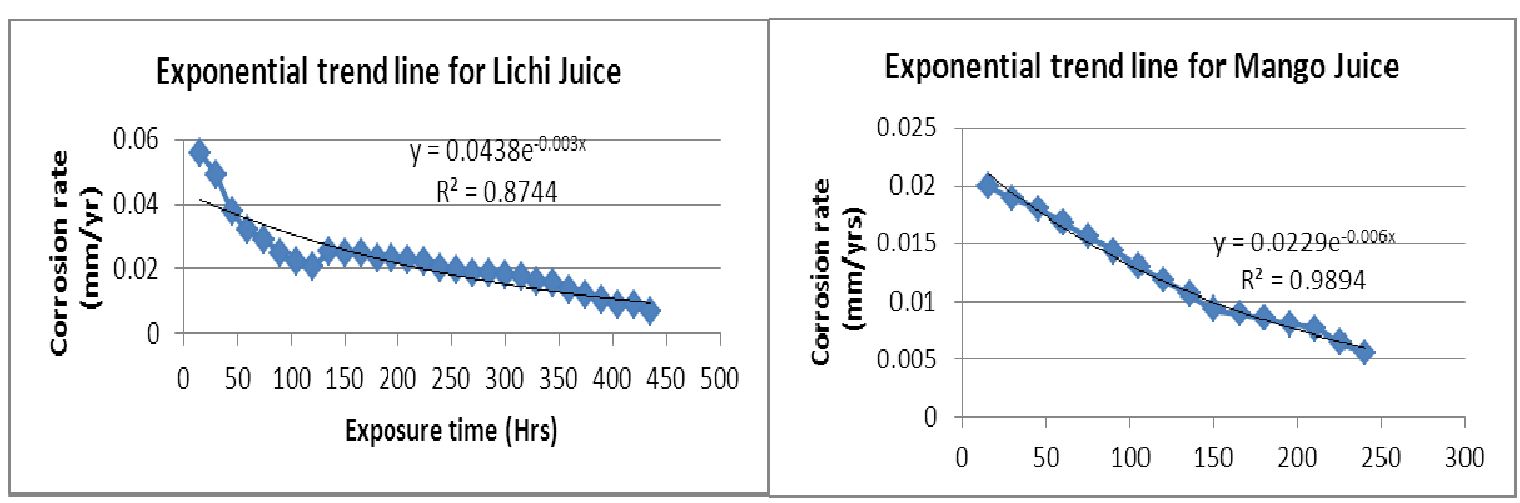

Co-relation graph for Lichi juice Co-relation graph for Mango juice

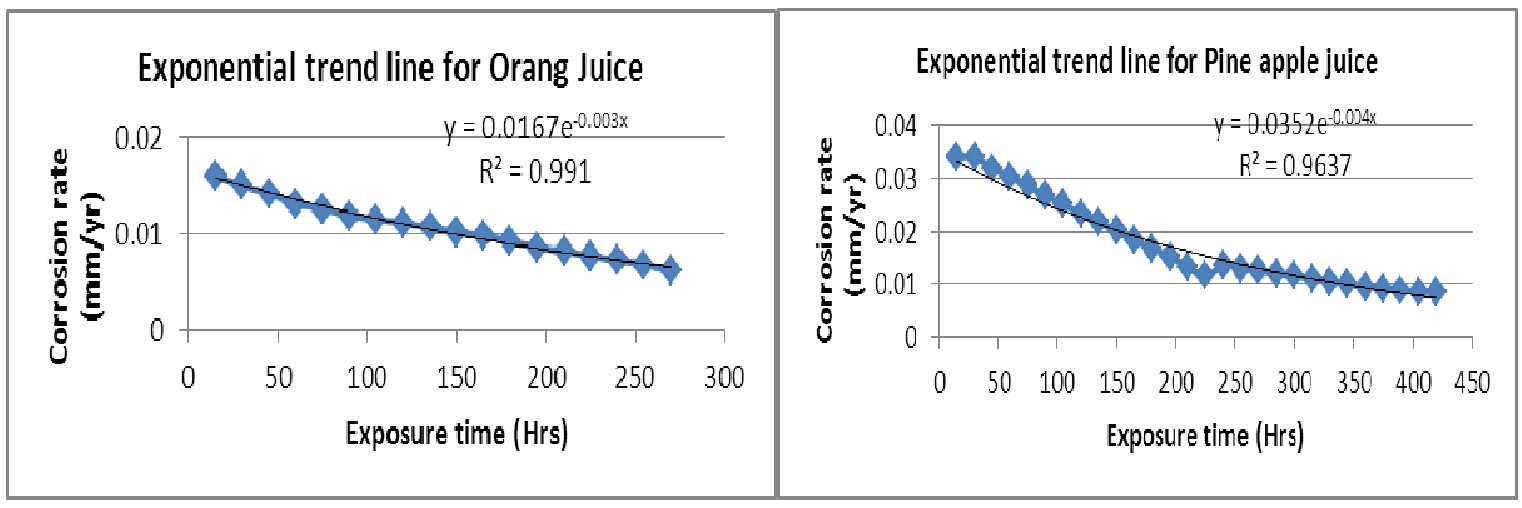

Co-relation graph for Orange juice Co-relation graph for Pine-apple juice

Fig. 9: Co-relation graph for 4 different variants( $\mathrm{R}=$ regression coefficient $)$ 


\section{IV.DISCUSSION}

In this section, test results and data analysis have been tabulated as below:

\begin{tabular}{|c|l|}
\hline Table no. & \multicolumn{1}{c|}{ Description } \\
\hline Table 3 & $\mathrm{pH}$ of all variant at a regular interval for 6 days. \\
\hline Table 4 & Weight loss of the sample in different variant \\
\hline Table 5 & Exposure time and corrosion rate of the sample in each variant \\
\hline Table 6 & Corrosion rate at $10^{\circ} \mathrm{C}$ and at $55^{\circ} \mathrm{C}$. \\
\hline Figure no. & \multicolumn{1}{c|}{ Description } \\
\hline Fig.5 & variation of $\mathrm{pH}$ vs no. of days \\
\hline Fig.6 & Corrosion Rate vs Exposure time for $11.2 \mathrm{gm} / \mathrm{m} 2$ tincoating \\
\hline Fig.7 & Co-relation graph for 4 different variants \\
\hline Fig.8 & Corrosion Rate vs. Exposure time for $5.6 \mathrm{gm} / \mathrm{m} 2$ tincoating \\
\hline Fig.9 & Co-relation graph for 4 different variants \\
\hline
\end{tabular}

Based on the results tabulated on the tables and figures as mention above, following observations can be made.

1. The factors that influence corrosion rates are the $\mathrm{pH}$ of the juices as illustrated in Table 3 . It is evident that the corrosivity of the media increases as the $\mathrm{pH}$ decreases. No any reaction was noticed on the lacquer side.

2. Table 5 represent the corrosion rate of tinplate $\left(11.2 \mathrm{gm} / \mathrm{m}^{2} \& 5.6 \mathrm{gm} / \mathrm{m}^{2}\right.$ coating) in different corrosive media at room temperature andTable 6 represent the corrosion rate of same tinplate sample at $10^{\circ} \mathrm{C} \&$ $55^{\circ} \mathrm{C}$ temperature. It is also clear from the data given in table 5 and table 6 that the corrosion process obeys the Arrhenius type reactions and corrosion rate increases with the temperature.

3. At the beginning of immersion period, tin coating was corroded by the present acid of the juices and with increasing immersion time, tin coating was corroded by aggressive solution due to potential difference between tin/carbon steel substrate of tinplate. At the end of the immersion period, because the coating/substrate interface was destroyed by aggressive solution, the corrosion product (as film) and tin coating came off from the surface in some area as illustrated in Fig.3.

4. The corrosion rate (as illustrated in Fig.6)is continuously in decreasing trend due to dissolution of surface tin up to exposure time 192 hours but above this, from 240 hours and onward the corrosion rate was in increasing trend due to exposure of alloy layer. Exposure above 315 hours the corrosion rate was increasing sharply.

5. It is also clear from the relation of Corrosion rate vs exposure time (Fig.6)and data describe in Table 5 obtained from Arrhenius equation that the Lichi juice and Pin apple juice have the high rate of corrosion compare to others. Corrosion rate Mango was in third position and Orange was in fourth position.

6. As illustrated in Fig.3 it is clear that for canning food that contains acid, it is necessary to use properly coated steel-base plate with the appropriate tin coating thickness. The tin coating should be differential 11.2/5.6 g. of tin (one side 11.2 and other side 5.6 coating). $11.2 \mathrm{~g}$ coated surface should be in contact of food and 5.6 coated surfaces should be outer side of the can for printing and lacquering.

7. There is a risk of food poising if food is canned in steel base coated with $5.6 \mathrm{~g} / \mathrm{m}^{2}$ tin. To avoid the food poisoning from corrosion of tin cans, food lacquer on the inner surface should be applied. Food lacquers have the high level of corrosion resistance, which isestablished as a right technique in the experiment.

8. In Table 5 it is shown that the corrosion rate was going to increase after 192 hours exposure time. Thus, there is a need to monitor the shelf life of canned foods; it is proven that prolonged exposure may have toxic effect on the quality of food caused by corrosion pollution.

\section{CONCLUSION}

- It was observed that tin coated mild steelcans are corrosive in fruit juice environments due to the evolution of hydrogen gas at low $\mathrm{pH}$ resulting in the possible elimination of the protective tin layer.

- It was also observed that corrosion rate was highest in the lichi and pine apple juice, mango and orange juices were in third and fourth position due to a combination of citric acid and the preservatives (food additives).

- As illustrated in the experiment, tin-coated sheets with $5.6 \mathrm{gm} / \mathrm{m}^{2}$ can be used for food packaging purpose if proper food grade lacquer is used. This may be a economic substitute for higher tin-coated sheets. 
Subsequently, corrosion of mild steel make undesirable health wise because the corrosion product goes into the fruit juice causing affect the taste, flavor and texture of the juices which may be hazardous to the health.For canning of food containing preservatives like citric acid, malic, tartaric, benzoic, succinic, oxalic and formic acids as an additive, use of adequately coated steel sheet with the pre designed customized combination of tin coating and lacquer film willbe costeffective and safe packaging. More research on corrosivity of different food items are required for dove tailing / optimal customizationof lacquer/ tin combination.

\section{REFERENCES:}

[1] Patel, A.S. and Talati, J.D. (1987) Corrosion of copper by Food acids containing colourants and sweetening Agents. Part IV, Paper presented 10th International Congress on Metallic (ICMC) Vol.:16:3, Madras, India.

[2] Abiola OK, Oforka NC, Ebenso EE (2004). The Inhibition of Mild SteelCorrosion in an Acidic Medium by Fruit Juice of Citrus Paradisi. J.Corr. Sci. Technol. 1: 75-78.

[3] Vogel, A.I. (1977). Qualitative Inorganic Analysis, Orient Longman Ltd.

[4] Haleem EI, Ald SM, Kheor MG, Killa HM (1980) Corrosion Behavior of Metals in HNO3, Br. Corrosion J. 6(1): p. 42.

[5] Kadoya, T. (1990) Food Packaging Academic Press Inc., California.

[6] Janaina CD, Jose DPG, Elliane D (2010). Corrosion inhibition of carbon steel in hydrochloric acid solution by fruit peel aqueous extracts. J. Corro. Sci. 52: 2341-2348.

[7] B.O Adewuyi \& O.A. Oladunjoye Corrosion of tinplate by Mallic Acid containing colourants and sweetening Agents, West Indian Journal of Engineering, Vol.27, No.1 (July 2004), 10-17.

[8] Sanusi Kazeem Oladele 1 and Hussein Kehinde Okoro 2 Investigation of corrosion effect of mild steel on orange juice. Department of Industrial Engineering, University of Stellenbosch, Private Bag XI, Matieland 7602 South Africa. 2Department of Chemistry, Faculty of Applied Science, Cape Peninsula University of Technology, P.O. Box 1906, Cape, Town, Bellville Campus, 7535, South Africa.

\section{AUTHORS PROFILE}

\section{Sourajyoti Dey :}

Mr Dey graduated with metallurgical engineering from NIT (then RIT), Jamshedpur. Subsequently he completed his masters in process metallurgy Subsequent to graduation he joined Tata Tinplate. Over his 20 years of experience, he has worked in projects, manufacturing, business excellence, quality, safety and strategy functions. He is actively involved in design and development of alloys for tinplate substrate and is actively pursuing new product and process developments.

In the early years of his career, he has graduated through the management education program at IIM Ahmedabad and subsequently in TQM concepts at JUSE, Tokyo. Applying thoughts of management, he has won the prestigious young managers competition organized by AIMA at the regional level.

He is a member of the global ISO steering committee for tinplate and a participative member of BIS steel and can committees. He is also a steering committee member of International Tin Research Institute (ITRI, London). He has (co)authored many technical and management papers in journals of repute.

\section{Dr Mahesh Kumar Agarwal}

Dr Agarwal has graduated with metallurgical engineering followed by his masters and subsequently a doctorate in metallurgical engineering from B.H.U. He joined N.I.T., Jamshedpur and has been associated with the institution donning various roles like being a Lecturer to Registrar and went on to head the department of Metallurgical and Materials Engineering. He has also been the Principal of Mining Institute, Koderma on lien from N.I.T., Jamshedpur.He is a active Member of various professional bodies such as Indian Institute of Metals, Institution of Engineers, Indian Society for Technical Education and Indian Red Cross Society.He has also (co)authored many technical papers in journals of repute and has been involved in the presentation of conference papers at both the national and international levels. 